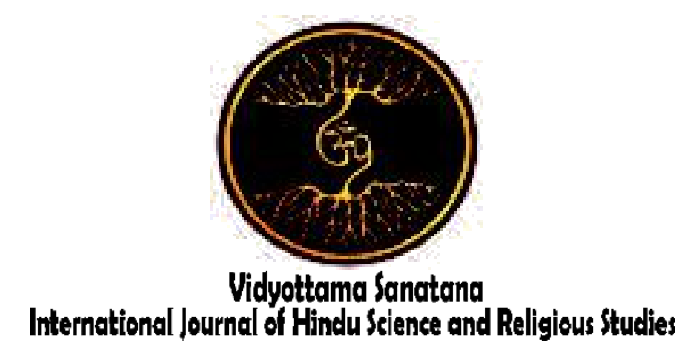

Vol. 4 No. 1 May 2020

\title{
DEVELOPING OF HINDU RELIGIOUS EDUCATION LEARNING MODEL BASED ON CHARACTER EDUCATION IN SMA NEGERI 1 PEKUTATAN
}

\author{
By: \\ Ni Ketut Srie Kusuma Wardhani \\ Universitas Hindu Negeri I Gusti Bagus Sugriwa Denpasar \\ E-mail : sriekusuma58@gmail.com
}

Received: May 12, 2020

Accepted: May 21, 2020

Published: May 30, 2020

\begin{abstract}
This research is a development research that emphasizes on the developing of Hindu religious education learning activities in SMA 1 Pekutatan. This study emphasizes on: identifying core competencies and basic competencies that are appropriated in developing, identifying themes and sub themes, models and approaches, and types of assessment that are appropriate to be developed in Hindu subjects based on character development. Theories used to dissect the problems in this study are Psychology learning theories as a Humanist Education Paradigm by Ausubel, and the K theory of Social Cognitive Learning Theories from Albert Bandura, and Theory of Social Change by Jean Piaget. The method used in this research is R\&D method that started with survey to identify problems until the revision model. Data obtained by conducting surveys using observations, questionnaires and interviews. The development of learning activities is validated by experts who have an educational background, culture and also character development education. Data analysis was analyzed descriptively qualitatively by explaining "Real Finding". The results of this study are the developing of Hindu religious education learning activity models to be valid and effective and the implications of their development. By including character development education, it can help students to develop student character early. Learning activities are designed to develop the character of high school students in Hindu subjects in SMA 1 Pekutatan. The results obtained from this assessment are: value learning approaches that insert character values that can help develop students' personalities and characters early on and can stimulate students to be more active in learning which results deeper values being implanted, moral reasoning, value analysis and spiritual culture understanding.
\end{abstract}

Keywords: Learning Activity Model, Character Education 


\section{INTRODUCTION}

Bali which is part of the Indonesian archipelago with dominant population as Hindus, is rich in diversity of natural resources. Bali has potential of natural resources and variety of good and interesting cultures, is also famous on its natural beauty that is so beautiful and promising like forests, mountains, beaches and lakes. To maintain the preservation of natural resources and cultural diversity, the provincial government of Bali has established conservation area to protect the sustainability of existing biodiversity and biodiversity. Various educational developments have been formed by the provincial government of Bali and spread in each district in Bali.

In Bali, there are several social phenomena related to moral crises, one form of change in the value system as revealed by Naisbitt and Aburdene in Megatrends 2000 is "weak religious beliefs, individualistic, materialistic and hedonistic attitudes" (Rahmat 1991: 71). This situation is contrary to Hindu teaching and does not support the achievement of national education goals. Objective conditions seen in various research data, revealed that the learning process has not been carried out optimally, so that its role as a subject oriented to the formation of the values of faith and devotion to God Almighty and noble character cannot be achieved effectively.

To anticipate this, the Ministry of National Education states that character education is a national program that aims to shape the nation's character and culture in students. The government's determination to make character development inseparable from the national education system must be taken seriously because in order to carry out character education, the government needs input, among others, concerning the models of character development and national culture as an inseparable part of the national education system.

Therefore the elements of character development must be integrated in all subjects and each teacher must be able to apply character education in every lesson. Integrating character education into subjects is most clearly seen in Civics and Religious Education subjects. Both of these subjects substantively should be able to provide character education so human moral fragility can be avoided. But the results of the analysis of the syllabus and learning materials of the two subjects at SMAN, especially on Hinduism subjects, showed that teaching materials for Hindu religious education subjects were only concern on cognitive and had not developed the material in the affective domain at all. Whereas Hindu studies should emphasize more on the affective domain because the content itself requires an understanding of the rules and noble values of Balinese culture.

The development of Hindu religious education is carried out to prepare Hindu human beings who can adapt and have quality, which is reflected through the ability to think, communicate, and behave in accordance with the identity of Hindu religious teachings based on the concepts of the teaching of the Tri Parisudha and Tri Hita Karana. This adjustment is intended to follow and integrate learning activities in a comprehensive manner so that later students can grow and develop into adults who are based on the noble values of the nation's culture that grows and develops in the community where students live are on. This is made clear by Sanjaya's opinion (2006: 25) which says that children must get education early to grow and develop according to the educational process carried out by educational institutions in their environment. Because learning activities are a process in which a person's environment is intentionally managed to enable students to shape changes in behavior by making adjustments to the environment.

Some things that caused the low role and effectiveness of religious education in forming students who believe and devote to God and noble character are: (1) Religious 
education has been carried out using learning approaches that are not in accordance with the objectives to be achieved, (2) Learning material Religious education is more theoretical, fragmented, isolated or less related to other subjects and even between sub-subjects of religion itself, (3) The learning model is conventional in that it emphasizes more on the enrichment of knowledge (cognitive at a low level) and on attitude formation (affective) and habituation (psycho-motor). So that religious education that aims to form students who have knowledge of religious teachings and are able to apply in the form of noble morals cannot yet be reached (Wibowo 2012: 52). Efforts to re-examine the implementation of Hindu religious education learning in formal educational institutions in particular, are increasingly pressing when related to reality in the field, such as; (1) there are various crisis of trust, which is marked by the emergence of tension, conflict in several regions. (2) Crisis of character that is characterized by the increasing number of crimes, both in the form of acts of violence such as; brawl, narcotics abuse and others which are always increasing every year (Republika 2002: 22).Through religious education held in schools properly, it is hoped that students will be able to avoid these despicable traits. The role of Hindu religious education is expected to overcome these negative impacts by using various models and strategies that can meet these challenges.

The development of Hindu learning models is not only cognitive understanding but also reflected in the affective and psychomotor aspects. Identifying character principles in education and learning that emphasizes the building of noble human relations between educators and students in passing down cultural values and to provide an overview of the principles developed, researchers discuss them through analysis of Lesson Study activities as an educational approach.

Based on observations at the time of conducting research site, it was found that the most difficulty experienced by Hindu religious teachers in SMAN Pekutatan was how the teaching strategy of Hinduism could encourage students to apply the values taught, namely silih asah, silih asuh, silih asih. This substantial aspect is obtained through an analysis of the thought process and the teacher's reflection on pedagogical interactions in the classroom recorded during Lesson Study activities. Therefore it is something that is very urgent to develop character education as a cornerstone of education and development in learning Hinduism which has the main goal of character building education based on religion and local culture.

Based on the above background, the researcher deems it necessary to know and study the Developing of Hindu Religious Education Learning Model Based on Character Education in SMAN 1 Pekutatan, Pekutatan District, Jembrana Regency, so that the elaboration of Hindu education in the future can reflect in the paradigm of Hindu education.

\section{METHOD}

This study uses sociological religion approach, religion aside from being belief is also a social phenomenon. It means the religion adopted gives birth to various social actions that grow and develop in life together. This research is also intended to describe the dialectical relationship between various forces in the community at the Research site (Lickona 2012: 72). Based on this view, this research is qualitative study generally defined as research that produces descriptive data in the form of words, symbols, and observable behavior. Thus if it refers to the thinking of (Triguna 1987: 137) that qualitative research is more humanistic and involves feelings. Data collection methods are: 1) observation, (2) interviews, (3) document studies and (4) library studies. Sources of data in this study are primary and secondary data sources, data sourced from empirical experience in community life and the information provided by the informant are classified as prime data sources. The selected informants were teachers, deputy principals, students, and 
community leaders. Data presentation techniques used in this study are narrative and writing are not interpretive or evaluative in nature. The theory used to dissect the problems in this research is psychological theory as an educational paradigm, social cognitive learning theory from Albert Bandura and social change theory. Data analysis was analyzed descriptively qualitatively by explaining "Real Finding". This research was conducted at SMAN 1 Pekutatan, Pekukatan Subdistrict, Jembrana Regency, the selection of the research location, because the process at the school had not yet integrated character education in Hindu religious education subjects and teaching strategies on teaching teachers were still conventional.

\section{RESULT AND DICUSSION}

3.1 Developing of Hindu Learning Model Activity Based on Character Education in SMAN 1 Pekutatan, Pekutatan District, Jembrana Regency

This research is research development that aims to develop a model of Hindu religious learning activities based on character education in SMAN 1 Pekutatan. The design of this study was developed based on the Frenkel (1990) model, which consists of three general phases, namely (1) preliminary study phase, (2) development study phase and (3) evaluation phase.

\subsubsection{Preliminary Study Phase}

At this stage 2 activities are carried out namely carrying out initial observations and analyzing the syllabus. The initial observation aims to look at the conditions in the class in connection with activities carried out in Hindu-based learning of character education. After the initial observation an analysis of the syllabuses was used in teaching Hinduism which is based on character education. The results of the two activities are as follows:

Initial observations were made with the aim of: (1) observing learning activities carried out in the classroom, (2) identifying various problems encountered including the determination of $\mathrm{KI}$ and $\mathrm{KD}$, themes / sub themes of teaching materials, approaches, methods and learning strategies, materials and media learning, and the types and forms of assessment. From the results of observations made are found as follows:

a. The results of the analysis of the lesson plan found that (1) in planning teacher learning still makes learning activities very traditional ie all teachers still use the lecture method and learning activities are still individual, (2) Still not explicitly written what character values are taught, so The teacher does not emphasize this

b. The results of observations on the teaching-learning process also show the same thing with the planning made. In fact it looks worse because in planning it is said to use Contextual learning methods but in the implementation of the RPP the activities carried out only use the lecture method.

c. In addition to the analysis of the lesson plan and observations when implementing the teaching and learning process there are some problems that are also found in Hindu religious teachers in SMAN 1 Pekutatan, Pekutatan District, Jembrana Regency, and it is difficult to determine indicators for achieving standards. This can be seen from the indicators which are only focused on the development of cognitive aspects. In addition, based on interviews with Hindu religious teachers Ni Made Sudiartini, S.Pd and Ni Nyoman Yani, S. Ag (interview 19 August 2018) it was also found that aspects of character development on each indicator were not included in the syllabus developed in schools.

d. In addition to the three activities above, in this preliminary stage a syllabus analysis is also conducted aimed at knowing IC, BC, and indicators and other aspects of the syllabus listed in the syllabus that has been developed in the relevant school. From the results of the analysis, we will find KI, KD, 
and which indicators can be used as a basis for character development education.

The syllabus, as the main product of curriculum development, is a learning plan consisting of competency standards, basic competencies, learning materials, learning activities, indicators, learning strategies, assessment, time allocation, and learning resources (Sutriyanti 2016: 16). Basically, the syllabus has 4 basic components that can be integrated with the learning components of each subject as a whole, namely: (1) Basic competency and competency standards, (2) Themes and sub-themes of character education that need to be developed in learning so that the intended competency device is achieved , (3) Approaches, methods, and learning techniques that are suitable to be developed so that the learning atmosphere of character development is reflected in it to achieve competence, (4) Techniques and types of assessment to assess learning outcomes of character education.

\subsubsection{Development Study Phase}

\section{a. Development of the Initial Draft Activity Model}

In this stage a preliminary draft of the model of Hindu religious learning based on Character education was developed. In learning at SMAN 1 Pekutatan, it was designed several approaches and methods used as a basis for developing Hindu-based learning activities in character education. The approaches used as a basis are: (1) Value-Based Learning Models, (2) Learning Models Based on Moral Reasoning Development, (3) Value Analysis Learning Models, (4) Value Classification Learning Models, (5) Project Citizen Learning Models, and (6) Spiritual Culture Based Learning Model; while the method used is the method of cooperative learning, participatory, inquiry, discussion, lecture, question and answer, assignment and socio drama which are also the learning activities. The learning procedure (syntax) of each approach and method can be outlined as follows.

1) Learning Activity Model for Value Investment

The model of investing activities assumes that students need to accept grades values that are considered noble and modern values that have been accepted by the dominant in society. The model of value learning activities like this comes from the ideological beliefs of perennial education and essentialism. According to the views of these two ideologies, the task of value education is to transmit noble values in society to students to enable students to take a role in society that is considered to have been established in the application of the main values derived from their outlook on life. The main characteristic of learning to instill values is that students must accept the values taught by adults and they must change values that are considered irrelevant by the dominant class in society. In Indonesian society that is religious and has religious values and already has Pancasila values that are considered to be established, this model of value planting is considered the most suitable application in value education in the context of shaping the nation's character. Learning instilling values can be done by direct learning methods or lectures, simulations, role playing, playing drama, learning by doing, and learning with positive and negative reinforcement.

2) Learning Activity Model Based on Moral Reasoning Development

This learning model is based on Piaget's cognitive psychology. According to this view, how people make judgments and decisions about values or morals is very dependent on their cognitive development, especially on the development of moral reasoning. According to Piaget, the development of moral reasoning is developing from a heteronomous level towards 
autonomous decision making. According to Kohlberg, as an expert on moral development, learning moral values is free and must facilitate the development of students' moral reasoning towards autonomous moral decision-making abilities. To facilitate students to be able to take moral decisions autonomously, they must be taught to deal with moral values dilemmas, learn to make moral decisions, and learn to give consideration of moral values by using rational reasoning. Through group discussion students are invited to discuss rationally why they have to take moral decisions as they face with a rational basis for thinking. The advantage of this learning model is that students are truly regarded as subjects who can make their own choice of moral values and provide rational moral reasoning without being bound by the values of certain groups including the dominant community. With these advantages students learn to develop reasoning rational values and morals so that they are able to make autonomous values and moral decisions.

3) Value Analysis Learning Activity Model

This learning model is still based on cognitive psychology as in the developmental model of moral reasoning. The main emphasis of this learning model is the ability of students to analyze values rationally and logically on social problems that contain moral values. Learning with this analysis exposes students to a variety of social problems in society that contain a conflict of moral values. The task of students is to conduct a logical analysis both through literature review, conducting field research, and through group or class discussions to discuss various value conflicts that occur in these social problems. To make decisions on the choice of values taken, students must develop their own criteria that are considered rational. This value analysis learning model is suitable for helping learners participate in solving social problems in society that contain conflicts of moral values by using logical, critical, and rational reasoning. The value analysis learning model can be done either by using individual or group tasks in solving social problems in the community through literature review, through investigative activities or social inquiry into the field, or through group discussions. The syntax of learning value analysis is as follows (Indrawan 2016: 30).

4) Value Clarification Learning Activity Model

The value classification learning model is a combination of the moral reasoning development learning model and the value analysis model, but it is not solely based on cognitive development. The focus on learning this value classification is to help students learn to take values and moral decisions and explain them for their reasons according to their own perspective. The difference with the cognitive development model is that in clarifying the choice of values, each student must be honest and open with themselves: how they feel, how their views and beliefs, and how their values and attitudes. With this learning model, learning does not only involve cognitive problems, but also involves aspects of students' beliefs and feelings in value decision making. The value clarification learning model can be done by using a value dilemma story, role playing followed by a value clarification discussion, dialogic discussion in solving social problems from the point of view of the student, the project method. Etc. The steps of learning value clarification are as follows:

5) Citizenship Project Learning Model This learning model helps students develop competencies good citizens in a democratic and participatory sense. 
Students are empowered to have social sensitivity and concern that also influences public policies by the government which contain moral values. Students in groups or classics are given the opportunity to develop projects to develop public policy proposals. In this model, students learn to identify social problems or identify community needs that can be helped to fulfill through public policy proposals that are developed by students themselves. After that, students learn to make various alternative solutions to problems and make recommendations for public policy proposals to relevant government officials. If the proposal can be accepted by the public or related government agencies, students then take action or action to realize public policies to meet the needs of the community. Furthermore students with educators can take action to reflect on the learning experience to assess the effectiveness of learning in achieving values / moral education goals (Aeni 2014: 12).

6) Spiritual Culture Based Learning Activity ModelThis learning model believes that the science approach and the religious approach can be synergized, such as adagium which states that science without religion is blind, and religion without knowledge is paralyzed. Learning values and morals with this model believes that the foundation of worship of knowledge to the community will provide a better community life. Through meaningful learning directed by learning goals for worshiping knowledge to the community, students by utilizing all the potential of their knowledge-sensory physical knowledge, kinesthetic knowledge, emotional knowledge, intellectual knowledge, social knowledge, moral knowledge, and spiritual knowledge-can help the community solve social problems they face. With this learning students learn to actualize the religious values they learn and learn science and technology to be worshiped to the interests of society (Raharjo 2010: 10). The steps of spiritual culture-based learning are as follows:

\section{Chart 1}

Steps of Spiritual Culture Based Learning

\begin{tabular}{|l|l|l|}
\hline $\begin{array}{l}\text { Phase 1 } \\
\text { Students make observations at } \\
\text { society about the problem they } \\
\text { face }\end{array}$ & $\begin{array}{l}\text { Phase 2 } \\
\text { By exploiting all potential his } \\
\text { knowledge (physical knowledge } \\
\text { senses, kinesthetic knowledge, } \\
\text { emotional knowledge, knowledge } \\
\text { intellectual, social knowledge, } \\
\text { moral knowledge, and knowledge } \\
\text { spiritual) help the community } \\
\text { solving social problems it faces. }\end{array}$ \\
\hline $\begin{array}{l}\text { Phase 3 } \\
\text { Actualizing religious values } \\
\text { kn learned and studied science } \\
\text { knowledge and technology for } \\
\text { worshiped in the interests } \\
\text { Public }\end{array}$ & $\begin{array}{l}\text { Phase 4 } 4 \\
\text { Learners with teachers can take } \\
\text { action on reflection } \\
\text { learning experience to judge } \\
\text { effectiveness of deep learning } \\
\text { achieving educational goals moral } \\
\text { values }\end{array}$ \\
\hline
\end{tabular}


In addition to the activity model above, the character values included in the basic competencies are as follows:

Table 1

Character Development in Some Base Based KD

Expert Test Results

\begin{tabular}{|c|c|c|c|}
\hline Class & Basic Competence & $\begin{array}{l}\text { Character which } \\
\text { exists }\end{array}$ & $\begin{array}{l}\text { Character that } \\
\text { needed to be add }\end{array}$ \\
\hline $\mathrm{X}$ & 4.1. Do visiting to the holy place & $\begin{array}{l}\text { Religious, Want } \\
\text { Know, Smart, } \\
\text { Confidence } \\
\end{array}$ & $\begin{array}{l}\text { Discipline and obey } \\
\text { to the social rule }\end{array}$ \\
\hline \multirow[t]{3}{*}{$\mathrm{XI}$} & $\begin{array}{l}\text { 3.1. Train yourself to make } \\
\text { facilities prayer }\end{array}$ & $\begin{array}{l}\text { Religious, Want } \\
\text { Know, Smart, } \\
\text { Confidence } \\
\end{array}$ & $\begin{array}{l}\text { Discipline and work } \\
\text { hard }\end{array}$ \\
\hline & $\begin{array}{l}\text { 4.1. Carry out holy days religious } \\
\text { in life }\end{array}$ & $\begin{array}{l}\text { Religious, Want } \\
\text { Know, Smart, } \\
\text { Confidence } \\
\end{array}$ & $\begin{array}{l}\text { Responsible and } \\
\text { Be aware of the } \\
\text { obligations }\end{array}$ \\
\hline & $\begin{array}{l}\text { 5.1. Train yourself to implement } \\
\text { Chess Paramitha and Tri Parartha } \\
\text { in life }\end{array}$ & $\begin{array}{l}\text { Religious, Want } \\
\text { Know, Smart, } \\
\text { Confidence }\end{array}$ & $\begin{array}{l}\text { Respect for } \\
\text { Diversity, } \\
\text { Comply with social } \\
\text { rules, and Conscious } \\
\text { of Obligations }\end{array}$ \\
\hline $\mathrm{XI}$ & $\begin{array}{l}\text { 5.4 Applying the teachings of } \\
\text { Panca Yama and Nyama Bratha } \\
\text { dalam } \\
\text { everyday life }\end{array}$ & $\begin{array}{l}\text { Religious, Want } \\
\text { Know, Smart, } \\
\text { Confidence }\end{array}$ & $\begin{array}{l}\text { Honest, Democratic, } \\
\text { Courteous, } \\
\text { Discipline, take } \\
\text { responsibility } \\
\text { answer, Appreciate } \\
\text { Diversity, Comply } \\
\text { with social rules, } \\
\text { Stylish healthy } \\
\text { living, } \\
\text { Be aware of rights } \\
\text { and obligation, Hard } \\
\text { work }\end{array}$ \\
\hline \multirow[t]{2}{*}{ XII } & $\begin{array}{l}\text { 2.1.Visit relics } \\
\text { the relics of the Hindu kingdom } \\
\text { local and other regions }\end{array}$ & $\begin{array}{l}\text { Religious, Want } \\
\text { Know, Smart, } \\
\text { Confidence } \\
\end{array}$ & $\begin{array}{l}\text { Discipline, polite, } \\
\text { To be responsible, } \\
\text { Obey social rules }\end{array}$ \\
\hline & $\begin{array}{l}3.3 \text { Carry out the Five Yadnya } \\
\text { in } \\
3.4 \text { daily life }\end{array}$ & $\begin{array}{l}\text { Religious, Want } \\
\text { Know, Smart, } \\
\text { Confidence }\end{array}$ & $\begin{array}{l}\text { Realize on } \\
\text { obligation }\end{array}$ \\
\hline
\end{tabular}

Based on the initial draft of the activity model above then the next stage is the expert test stage. In this stage the model of Hindu learning activities based on character education and learning syntax is asked for validation from experts. There are two experts who are used as expert judges in this stage, namely: Prof.Dr.Anak
Agung Gede Agung, M.Pd and Prof. Dr. Ida Bagus Yudha Triguna, MS. Expert test results show: Criteria used to select expert judges are: (1) Professor, (2) has more than 10 years of teaching experience, (3) has expertise in learning, (4) has experience in guiding students $\mathrm{S} 1, \mathrm{~S} 2$ or $\mathrm{S} 3$ in research and design $(\mathrm{R} \& \mathrm{D})$ 
and (5) are willing to become judges. The results of expert validation are obtained as follows:

a) The Model of Hindu Character Based Learning Activities (APAHBPK) has clearly identified goals

b) Concentration (area) of the purpose of the APAHBPK is clearly stated

c) The characteristics of APAHBPK are explained explicitly and implicitly.

d) The procedures for implementing APAHBPK are explained explicitly and implicitly.

e) The facilities and infrastructure for implementing the APAHBPK are available

f) The APAHBPK model developed in accordance with the implemented curriculum

g) The APAHBPK model is in accordance with the principles of learning and teaching principles

h) The APAHBPK model developed has followed the principles of evaluation

i) The APAHBPK model can help students categorized as 'sloe leraners' to be able to have better learning outcomes

j) The APAHBPK model developed can motivate students to always implement character values

k) The APAHBPK model requires teachers to be more creative and innovative.

\section{b. Revision Model}

This stage is carried out if input from experts is obtained in connection with the APAHBPK model. Based on the input already given, there is no revisions were given by the two experts. Therefore the next stage carried out in this research development is empirical testing or evaluation. Given the limited time, empirical tests carried out are very limited in only the Nine Classes. From the results of the empirical test, it can be said that almost all APAHBPK models implemented in the RPP are approved by almost $88.5 \%$ of teachers. Thus the APAHBPK model is in the good / good category.

\subsection{Implications of the Developing of Hindu Religious Learning Model Based Activity Character Education in State Students 1 Pekutatan District Pekutatan Jembrana Regency.}

\subsubsection{Strengthening of Religiosity}

Implications of the Developing of Hindu Education Learning Models Based on Character Education in Students in SMAN 1 Pekutatan, Pekutatan District, Jembrana District, have great influence, especially in the assessment of students' religious / devotion attitudes. Religious is an attitude and behavior that shows confidence in the existence of the power of the creator or God Almighty. This belief is accompanied by obedience and obedience in following orders and avoiding all His prohibitions. Religious attitude is the main thing in the teacher's attitude assessment sheet. Although this attitude assessment is sometimes ruled out in the contribution of report cards as students' graduation, the essence of attitude values is the most important thing compared to the cognitive scores or skills of students (Sudiartini, Interview on 7 August 2018).

According to Nyoman Yani (Interview 7 August 2018) stated, in the 2013 curriculum namely aspects of teacher assessment of students there are 3 assessment sheets, namely: List knowledge scores, list of skills scores and student attitude observation sheets. Where the assessment of student devotion attitudes included in the third assessment indicator is the assessment of students' attitudes. Teachers should pay more attention and attention to this attitude 
observation sheet, which is sometimes ignored by teachers' assessments. Talking about the problem of taqwa will never be separated from the scope of religion, because religion is a path or belief adopted by someone in devotion to his Lord. If religion has become an integral part in the person of every Hindu, religion will be seen in all human behavior both individually and collectively (Wiana 2010: 72). Devotion to God begins with confidence in yourself, by first believing in the existence of God and all his teachings. People who are said to have a good attitude of devotion will always be obedient, diligent and sure to move towards something related to God or strength that is beyond the limits of human strength. Religious is the appreciation and implementation of religious teachings in everyday life (Naim 2012: 124). Religious attitude is a reflection of believers who have a firm belief in God Almighty. In the book Rgveda IX.64.21 explained:

\section{Abdhi venā anūsateyaksanti \\ pracetasah \\ Mjjanty-avicetasah}

\section{Translation:}

People of faith in God who are educated presenting prayers and enlightened religious scholars intend to offer the yajna. People who do not believe in God Almighty, and fools will sink (Titib 2006: 67).

The Sloka clearly emphasizes that people who believe in God Almighty, learned people always offer prayers of praise. People who do not believe in God Almighty and ignorant people will sink to the brink of suffering. Therefore, being human must always strengthen Sradha and devotion to God Almighty because humans are nothing before God. The Book of Slokantara 9 is explained:

àpadgato 'pi dosājna dharmasastram
na warjayet,
saroruhun yathā bhrngaschinnpakso
pi jñatibhi
Translation:

A person who is staunch of a priest, even if he is in distress or a major Disaster, he will not want to violate the provisions and the Advice of the scriptures. Same with beetles who will not want to leave flower blossoms even though their wings are pulled (Sudharta 2001: 32).

Based on the slokantara sloka above, it explains people who have high level of religiosity, characterized by a firm attitude of faith despite facing all kinds of challenges such as disaster, and being hurt by others, he remained steadfast and loyal to the advice of the scriptures that became his conviction. One example that can be seen in students of SMA 1 Pekutatan regarding good religiosity / devotion is as follows:

1. Be diligent Tri Sandhya / Prayers, upon arrival at school go directly to Padmasana to carry out prayers and in class before the lesson starts the first hour after the bell starts ringing the students in an orderly manner and fervently performs Tri Sandya puja in class.

2. Students assigned to picket always diligently bring canang sari and arrange it in every pelinggih / pelangkih in the school environment, and always bring a means of worship such as: banten, canang sari, kuangen, flowers and incense when full moon / tilem in carrying out joint prayers at school.

3. Students always carry out maturity training in padmasana / pelinggih schools in starting or ending the learning period at school.

In accordance with the Theory of Behavior Change that was revealed by Allport stated that Behavior or attitude of a person is formed from habits from birth, so in this case the spiritual attitude of the students must be instilled early on, starting from family education, elementary school, junior high school and high school / K. To fix the spiritual attitude in high 
school needs to be supported with high confidence, because it needs habituation. Through habituation carried out in SMA 1 Pekutatan in instilling religious / spiritual attitudes of students, especially in the attitude of devotion such as: obedience to pray at school, routinely provide understanding of religion, hold regular Dharma Discourse activities, conduct activities that are religious (religious pesantian, yoga, mejejaitan, dance and percussion). With habituation like this, changes in students will occur, especially in religious / spiritual attitudes and student devotion in SMA 1 Pekutatan.

In its realization, as a form of love, various things are best presented by humans. A farmer will offer the best results achieved. An artist will try to manifest a sense of devotion by manifesting sacred or beautiful symbols about God. Thus, the growth and development of various expressive symbols and actions in relation to the majesty of God and the sign of human resignation to a higher power.

\subsubsection{Improvement of Honesty Attitudes of the Student in SMAN 1 Pekutatan}

Honesty is very important thing in life almost anything based on honesty. Honest attitude is needed in various aspects of life, especially in the learning stage at school. Honesty does not only include the notion of lying or telling the truth, but also the act of not taking what is not his right (Ani 2014: 108).

The attitude of honesty that grows from the heart in a person. If this attitude of honesty is fostered from childhood and becomes a habit in life that will be carried into old age. So the attitude of honesty must be fostered early on, starting from being honest with oneself, with family, friends, and the community in general. A good behavior starts from a good attitude of honesty since childhood. As in the theory of behavior change according to Allport said, "Changes in behavior can be seen from developments personality from birth to child in adulthood (Nobes dan Hall 1995: 25). Personality that is nurtured since childhood will determine the development of behavior in adulthood, so it is very difficult if the attitude of honesty must be changed when it becomes an adult. Like the honesty attitude of high school students Collaboration that gets more attention to be developed in a better direction Teachers must look for relevant ways to develop honesty attitudes in various aspects such as: during the test students must be closely monitored, so that students no longer have the opportunity to cheat.

Even if there are students who are caught cheating it must be firmly punished so that it can become a deterrent effect and no longer repeat their actions. By accustoming students to such situations, at least the attitude of honesty is slowly starting to increase. So the attitude of honesty can be changed through the rules that have become a habit in the environment. Although it feels difficult, but it is not impossible to change the attitude of honesty in a person. Starting from giving religious advice, lectures and spiritual deepening which states that the attitude of dishonesty is something wrong and sinful when someone is not honest in live the life. So that the steps taken in developing this attitude of honesty are in line with the realization of the teachings of wirya. Where the teaching of wirya emphasizes the determination in carrying out the truth (Dharma) such as: not cheating at the time of the test, being honest in saying what is according to the truth, and carrying out all the utterances in accordance with the promises of students that are said every Monday at the flag ceremony. 


\subsubsection{Formation of Discipline Attitudes Students in SMAN 1 Pekutatan}

Discipline is an action that shows an orderly and compliant behavior with various rules and regulations. Discipline is compliance to respect and implement a system that requires people to submit to decisions, orders, and regulations. It also means that discipline is an attitude of obeying rules and regulations that have been applied unconditionally. Discipline is a mental attitude that is reflected in the behavior of individuals, groups or communities in the form of compliance and obedience to the rules, regulations, ethics, norms and applicable rules. Someone's discipline can be trained to become embedded and become a habit in a person starting from the discipline of time, dressing, talking and acting behavior. Discipline in SMA 1 Pekutatan is of extreme concern, especially for students who are active in the school environment. Starting from the time discipline, where students are required to come before the bell rings $(07.30 \mathrm{pm})$. Especially for Monday at 07.00 wita the bell has sounded because there was a flag ceremony apple. For students who come being late is usually subject to sanctions and is noted by the BK teacher's name.

Furthermore, discipline in dressing, this is usually most often violated by students because of fashionable reasons, so many students who modify their school uniforms such as model clothes that are reduced so that it violates the school rules. Through the teachings of wirya namely perseverance, determination carry out the dharma high integrity attitude especially in terms of discipline in the truth (dharma). Discipline attitude of students can be trained through activities held at school such as: LKBB (Line-Up Skill Competition) which is usually contested between classes or schools, a walking contest, a Flag Ceremony and other activities that support and train student disciplinary attitudes.

To instill a good attitude of discipline, especially in the cleanliness of the school environment. Teachers and guardians agree to create a cleanliness program in the form of the cleanest and dirtiest class championship system every week. Each classroom and its environment were assessed for the cleanliness and completeness of the class by the assigned teacher. Furthermore, the results of the cleanliness class recap will be announced every Monday after the flag ceremony. The class that gets the cleanest title gets congratulations from the school principal and gets a rotating trophy that can later be displayed in the classroom for 1 week. Furthermore, the class that gets the dirtiest title gets a penalty or penalty in the form of cleaning an area such as the teacher's room, toilet, library and other environments.

Through this cleanliness program which is an actualization in terms of instilling an attitude of discipline to be more improved, especially discipline in terms of classroom cleanliness and the environment. Classes that were once dirty, not well cared for so that they become cleaner and orderly are certainly very beneficial to continue to be developed in the school environment. In addition to religious activities, discipline is also carried out when children carry out their daily obligations. Discipline of students to get up in the morning is done routinely by students to prepare themselves for school. Starting daily activities carried out by children starting with waking up at 6:00 in the morning, followed by bathing, wearing clothes, eating, and going to school (Interview with sudiartini, August 27, 2018). 
Spiritual attitude and selfdiscipline attitude in all things is an actualization of the spiritual attitude itself such as: time discipline, prayer discipline, learning discipline, dress discipline, speaking discipline and disciplined in taking lessons while learning with the theme of Asanas Yoga as shown in the picture below. discipline in action. Therefore it can be concluded that the attitude of discipline is the initial capital in achieving a success. The results of observations by researchers found that students were very attentive and

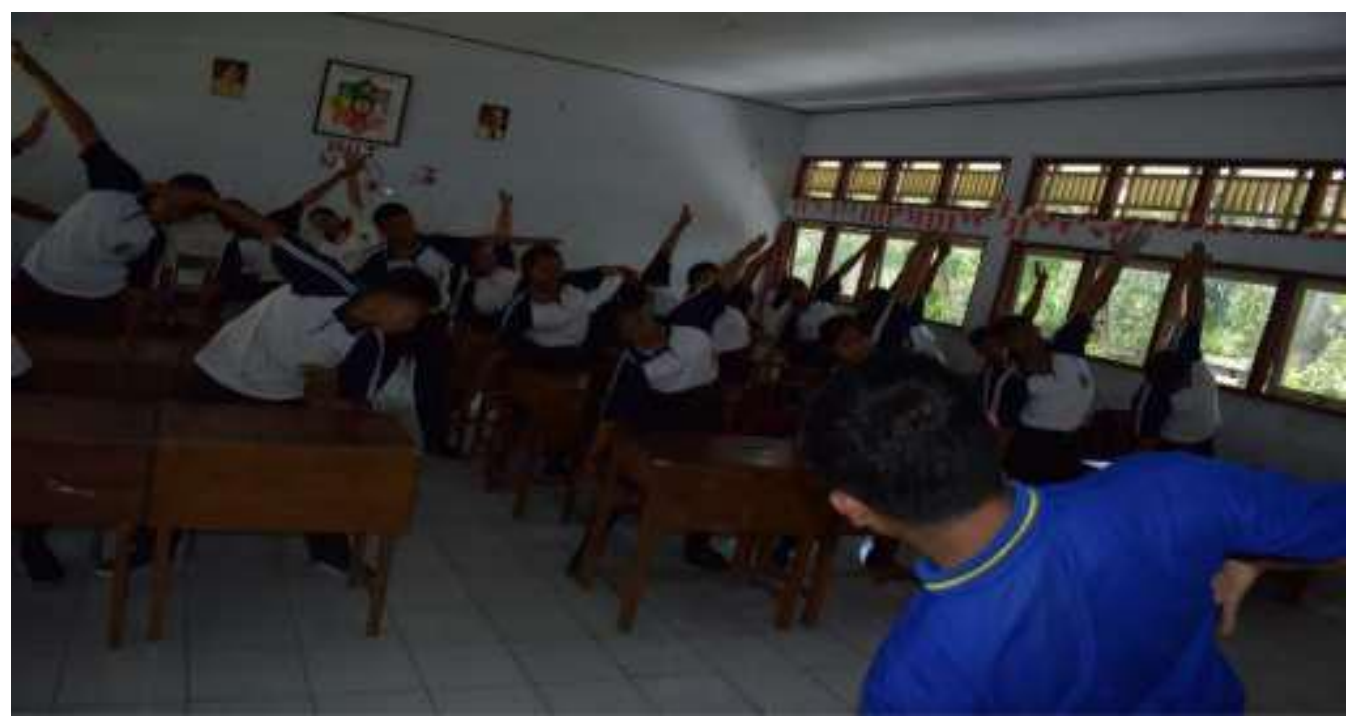

Picture 1

Students are following the Asanas yoga movement Source: Researcher Documentation 2018

Behavioristic theory with its stimulus-response relationship model, seeks people to learn as passive individuals. Specific responses or behaviors using training or habituation methods only. The appearance of behavior will be stronger if given reinforcement and will disappear if subject to punishment. Learning is a result of the interaction between stimulus and Slavin's response (Ariawan 2017: 38). Further explained that behaviorism is a theory of behavior change as a result of experience. In relation to human behavior, the theory of behaviorism views individuals as reactive beings who respond to their environment.

Discipline conducted by students of SMA Negeri 1 Pekutatan in the teaching and learning process in Class can be said to be good. Although there are students who lack behavior that is not disciplined. Overall discipline is carried out. Discipline that takes place cannot be separated from the role of the teacher in providing disciplinary exercises in carrying out daily activities so that students are accustomed to doing well. Likewise with the school community, discipline was shown in daily activities, Interview with Student Deputy, I Gusti Ngurah Komang Kusumayadi (August 14, 2018).

\subsubsection{Implications in Fostering Attitudes of Students 'Concern for SMAN 1 Pekutatan.}

In this day and age, individualists are increasingly mushrooming by always being selfish. Due to the demands of life increasingly difficult and people are competing to pursue their needs with all their desires. This indirectly makes people 
increasingly thinking or selfish. Very inversely proportional to the principle of life of Hindus who embrace the teachings of Tat Twam Asi. The teachings of Tat Twam Asi. is the teaching of compassion, which means all that is you, I am you and you are me (Suhardana 2006: 56).

According to Nata (interview on August 7, 2018), stated that the attitude of caring in school that must be realized by students is not just because of the assessment alone, the attitude of care that arises from the instincts of students that can be seen through daily actions, attitudes and behavior. The attitude of concern for students in SMA 1 Pekutatan which can be seen include:

1. Fellow students have good affection, not only because they have a special relationship such as dating, but love is meant in terms of establishing friends or study partners.

2. Students show concern for fellow students, teachers and school residents and their environment in maintaining school hygiene. Learners who care will not damage the environment let alone littering.

3. Students establish good communication between fellow students, both with the upperclassman and the subclass. Where communication or exchanging greetings with friends is the simplest feature of caring.

4. Learners share, meaning students care about friends or his friend by giving something both material and non-material needed by others.

5. Students forgive each other when a mistake or dispute occurs, forgiving means having a concern to give an opportunity to change towards a better life.

6. Students are able to establish good relationships with fellow students and with teachers. Relationships that are meant to be harmonious relationships in establishing care in the field of teaching and learning as well as other spheres. The attitude of concern that is realized in SMAN 1 Pekutatan is very useful for social life in living life. People who have a high attitude of caring, have been able to control the ego in themselves and grow abundant affection.

\subsubsection{Implications in fostering the \\ Responsibility of Students' \\ Attitude SMAN 1 Pekutatan}

The obligation of a student is to obey the rules of school rules both regarding the learning process and the obligation to pay tuition fees at school. When one of the obligations is not fulfilled, it can be said that the students are less responsible in carrying out their obligations at school. Students who have more responsibility are students who always carry out what has become their obligation, and students who do not carry out their obligations must get a sanction according to the rules or school rules.

Rai Gelgel (School Principal) (Interview on September 7, 2018) stated that many students have already made improvements in the responsibilities of schooling. For example, students who get pickets must be responsible for cleanliness, completeness and other needs in preparing for class learning. Through the existence of strict sanctions given to students who violating or not carrying out its obligations properly must receive sanctions that are proportional to their mistakes.

From the description above it can be concluded that the attitude of responsibility is an attitude of awareness in human beings where a person already has a strong integrity that is able to say according to his actions, and take full responsibility for what has been done. This attitude of responsibility is the benchmark for the realization of the model of character education development in Hindu religious learning. 


\subsubsection{Implications of Growing Respect for Respect}

Respect is an attitude of appreciation, admiration, or respect for other parties. Respect is very important in everyday life. Students are usually taught to respect parents, siblings, teachers, adults, school rules, traffic rules, family, and the culture and traditions adopted by the community. Respect for respecting the SMA Negeri 1 Pekutatan school family manifests itself in respect for the family, other people, leaders, plants and other creatures as God's creation. Respect embodies respect, mutual love, and love each other so as to create a harmonious life.

Respect in the family of SMA 1 Pekutatan is shown in the behavior of students who listen and carry out the advice of teachers, school leaders, and parents. When advised, children do not fight parents. Changes in behavior after being given advice students do not repeat the mistakes made and run in accordance with the instructions of the teacher and extended family of SMA Negeri 1 Pekutatan,

According to one of informant named Tri Suandeni's, students of SMA 1 Pekutatan basically have high respect for their teachers, friends and parents. Every advice given will be listened carefully and carried out according to the instructions. Although in its implementation students sometimes violate it. When the violation occurs, it is immediately advised not to repeat (Interview, 17 September 2018).

In addition, a teacher, homeroom teacher, and school staff also have respect for students when students pour out their desires and tell stories about their daily listening together. Listening to students' stories has important meaning for teachers or parents because they must be able to show mutual respect for students. Students want to hear the advice of their teacher, otherwise the teacher must also be able to hear the story of students to establish communication in the family. This atmosphere occurs when students gather together with extended family of SMAN 1 Pekutatan.

Another respect is also shown. As Rai Gelgel stated that when meeting with other students greet each other when they know each other but when they meet strangers, children in Pekutatan Village show respect by not disturbing (Interview, 2 September 2018).

\subsubsection{Implications in Implanting the Manners of Public High School Students' Behavior SMAN 1 Pekutatan}

According to Kusumayadi (Interview 7 September 2018), stated that the planting of polite attitude of students in SMAN 1 Pekutatan is always emphasized in each opportunity to give lectures, give advice, or through the mandate of the school principal at each flag ceremony. To understand the importance of manners between human beings for a better life. So that the attitude of courtesy among students can be maintained and always applied in everyday life. Through advice given to students, students are expected to understand more about the meaning that it is important for humans to maintain a polite attitude towards others, because human beings are actually social creatures. As social beings humans cannot live without other humans. Humans have an instinct to live together, live in groups, socialize and help one another. The attitude of courtesy is the main thing in socializing with others, because it is by showing a polite attitude that a person can be valued with his or her existence as a social creature. When someone is sick, has problem or human disaster needs someone else, this proves that humans need to be in the midst of other human beings (Sanjaya 2011: 109). In the life of 
socializing among humans, it is of course obedient to the norms and ethics in making relationships with others.

Manners have a lot of good influence on themselves and others. According to (Lumut dan Watulumbang 2019: 19) states that human morals are human beings who possess, live and carry out ethical human values according to norms and virtuous politeness. Thus humans in living their lives in a social environment must always uphold the values or norms that apply in social life.

Through precepts and precepts are very relevant, because precepts and precepts emphasize the ethical, moral and manners of fellow human beings. When the precepts and ideals are perfectly realized in life, especially in the environment of SMA 1 Pekutatan, comfort, harmony and harmony of life will always be maintained according to the rules, customs and norms that apply.

\subsubsection{Implications in growing the Student' Proactive attitude SMAN 1 Pekutatan}

According to Hartawan (Interview on 7 September 2018) stated the proactive attitude of students in schools is very necessary in the teaching and learning process. Building a proactive attitude is very useful for students especially in dealing with obstacles in interacting with others. Proactive attitudes show high emotional intelligence (EQ). Someone can survive when faced with problems, can foster motivation to learn when conditions are not pleasant, all of that is a proactive attitude that shows good emotional management within. Proactive attitude assessment contained in the student attitude assessment sheet, generally done through direct teacher observation.
Where the teacher observes the proactive attitude of students both in the teaching and learning process in the classroom and in carrying out daily activities in the school circle.

The teachings of high morality are in line with the development of students' proactive attitudes in SMAN 1 Pekutatan who have a wide range of vocational skills are very important to show a proactive attitude in developing students' knowledge and skills competency in accordance with their majors. A positive proactive attitude can facilitate solving a problem that occurs, especially in teaching and learning process for example, by always coordinating with fellow friends or with the teachers. Through this relationship, of course, it must be based on ethics, ethics and good understanding (Sutriyanti, 2019: 29).

Active students ask when they find difficulties in the teaching and learning process. The activeness of students in the teaching and learning process at school plays an important role in the success of educational success. Where when students do not understand the material delivered by the teacher, a student proactively looks for the teacher and asks for material or things that are not yet clear. So that with a proactive learning condition, all problems or problems can be resolved. In practice students must actively communicate with the environment, both with the teachers and with their friends, of course, through good manners, ethics or good morals.

\section{CONCLUSION}

The Model of Hindu Religious Learning Activities Based on Character Education is an activity model that uses various value learning approaches that are developed by inserting character values in their learning. Insertion of character values in the APAHBPK model can help develop the personality and character of students from an 
early age. The APAHBPK model can stimulate students to be more active in learning, which has an impact on the deeper value inculcation, moral reasoning, value analysis, and understanding of the spiritual culture of the students concerned.

Implications of the Development of Hindu Learning Model Activity Based on Character Education in SMAN 1 Pekutatan, namely: (1) Strengthening of Religiosity, Harmonious Life based on Tri Hita Karana, Religious is an attitude and behavior that shows confidence in the existence of the power of the creator or God Almighty. This was manifested through; Diligent Tri Sandhya / Pray, perform prayers and in class before class begins the first hour after the bell rings the students ring in an orderly and solemn way of performing puja Tri Sandya, and pray on certain days. (2) Increasing the attitude of honesty in students, this is done by the realization of the wirya teaching. Where the teaching of wirya emphasizes the determination in carrying out the truth (Dharma) such as: not cheating at the time of the test, being honest in saying what is according to the truth, and carrying out all the utterances in accordance with the promises of students that are said every Monday at the flag ceremony. (3) Formation of Discipline Attitudes Learners, Discipline a person can be trained to be embedded and become a habit in a person starting from the discipline of time, dress, and talk and behave. Discipline in SMAN 1 Pekutatan is of extreme concern, especially for students who are active in the school environment. Starting from the discipline of time, where the students carry out the teachings of wirya namely perseverance, determination in carrying out high integrity dharma, especially in terms of discipline in the truth (dharma). Attitude of caring is the actualization of the teachings of Tat Twam Asi with the basic principles of love, care, attention, understanding and penance. Fellow students have good affection, affection which is meant in terms of establishing friends or study partners. (5) In fostering attitudes Responsibility Learners is an attitude of awareness in humans where someone already has strong integrity that is, able to say according to his actions, and take full responsibility for what has been done. This attitude of responsibility is the benchmark for the realization of the model of character education development in Hindu religious learning. (6) Implications of Respect. Respect is manifested in respect for family, others, leaders, plants and other creatures as God's creation. Respect embodies respect, mutual love, and love each other so as to create a harmonious life. (7) Instill polite manners Students are always respectful and polite to every human being especially to the teacher always using polite words in communication in the school environment especially to the harsh words, wearing polite clothes according to school rules, not inclusion of lifestyle trends that become fashions or modes of course that are not in accordance with the school culture of mutual affection and respect for fellow students and teachers. (8) Implications in growing attitudes Proactive Attitudes Learners, proactive attitudes show a high attitude of emotional intelligence (EQ). Someone can survive when faced problems, can foster motivation to learn when conditions are not pleasant, and show an active attitude such as: diligently asking questions, diligently answering, often discussing, often exchanging greetings with the teachers, establishing good communication and often participating in various activities at school.

\section{REFERENCE}

Aeni, A. N. (2014). PENDIDIKAN KARAKTER UNTUK SISWA SD DALAM PERSPEKTIF ISLAM. Mimbar Sekolah Dasar. https://doi.org/10.17509/mimbarsd.v1i1.863

Ani, N. A. (2014). Pendidikan Karakter untuk Siswa SD dalam Perspektif Islam. Mimbar Sekolah Dasar.

Ariawan, R. (2017). PENGARUH PEMBELAJARAN VISUAL THINKING DISERTAI AKTIVITAS QUICK ON THE DRAW TERHADAP KEMAMPUAN PEMECAHAN MASALAH DAN KOMUNIKASI MATEMATIS. Jurnal Penelitian dan Pembelajaran Matematika. https://doi.org/10.30870/jppm.v10i1.11 93 
Indrawan, I. (2016). PENDIDIKAN KARAKTER DALAM PERSPEKTIF ISLAM. Al-Afkar : Jurnal Keislaman \& Peradaban. https://doi.org/10.28944/afkar.v2i1.90 Lickona, T. (2012). Educating For Character( Mendidik Untuk Membentuk Karakter). Jakarta: Bumi Aksara.

Lumut, B., \& Watulumbang, L. (2019). NILAI-NILAI PENDIDIKAN KARAKTER DALAM. 6(September), 612.

Naim, N. (2012). Character Building. Yogyakarta: AR. Ruzzmedia.

Nobes, C. D., \& Hall, A. (1995). Rho, Rac, and $\mathrm{Cdc} 42$ GTPases regulate the assembly of multimolecular focal complexes associated with actin stress fibers, lamellipodia, and filopodia. Cell. https://doi.org/10.1016/00928674(95)90370-4

Raharjo, S. B. (2010). Pendidikan Karakter Sebagai Upaya Menciptakan Akhlak Mulia. Jurnal Pendidikan dan Kebudayaan. https://doi.org/10.24832/jpnk.v16i3.45 6

Rahmat, M. (1991). Sosiologi Pedesaan: Studi Perubahan Sosial. Malang: UIN Malang Press.

Republika. (2002). Makalah. Yogyakarta: Pustaka Belajar.

Sanjaya, P. (2011). Filsafat Pendidikan Agama Hindu. Surabaya: Paramita.
Sudharta, T. R. (2001). Slokantara. Surabaya: Paramita.

Suhardana, K. (2006). Pengantar Etika dan Moralitas Hindu, Bahan Kajian untuk Memperbaiki Tingkah Laku. Denpasar: Paramitha Surabya.

Sutriyanti, N. K. (2016). PENINGKATAN MUTU PENDIDIKAN KARAKTER MELALUI PERAN ORANG TUA DALAM KELUARGA. Jurnal Penjaminan Mutu. https://doi.org/10.25078/jpm.v2i1.57

Sutriyanti, N. K., Marsono, M., \& Alit Supandi, I. N. (2019). Sad Dharma As A Learning Method Of Hindu Religious Education And Character Of 2013 Curriculum In SMP Gurukula Bangli. Vidyottama Sanatana: International Journal of Hindu Science and Religious Studies. https://doi.org/10.25078/ijhsrs.v3i1.65 0

Titib, I. M. (2006). Menumbuhkembangkan Pendidikan Budhi Pekerti pada Anak. Denpasar: Pustaka Bali Post.

Triguna, B. G. Y. (1987). Teori-teori Sosiologi Dalam Kerangka Paradigma. Denpasar: IHDN.

Wiana, I. K. (2010). Bagaimana Menjadi Hindu. Surabaya: Paramita.

Wibowo, A. (2012). Pendidikan Karakter: Strategi Membangun Karakter Bangsa Berperadaban. Yogyakarta: : Pustaka Belajar. 